\title{
Ultrasound-assisted extraction of medicinal plants and evaluation of their biological activity
}

\author{
Gadjalova, A.V. and *Mihaylova, D.Sp. \\ University of Food Technologies, Technological Faculty, Department of Biotechnology, 26 Maritza Blvd., \\ 4002, Plovdiv, Bulgaria
}

\section{Article history: \\ Received: 26 March 2019 \\ Received in revised form: 6 April 2019 \\ Accepted: 8 April 2019 \\ Available Online: 12 April 2019}

\section{Keywords:}

Biological activity, Medicinal plants,

Ultrasound-assisted

extraction,

Antioxidant potential

DOI:

https://doi.org/10.26656/fr.2017.3(5).128

\begin{abstract}
Nowadays, medicinal plants used in folk medicine are being increasingly studied and used in pharmaceutical, food and nutraceutical fields. Ultrasound-assisted procedure is extensively used recently for the extraction of valuable molecules. The study objective was to investigate total phenolic content using Folin-Ciocalteu's method and determine the antioxidant capacity in Centaurium erythraea Pers., Glycyrrhiza glabra L., Polygonum hydropiper L., Silene vulgaris L., Aspalathus linearis L., Helichrysum arenarium (L.) Moench., Sambucus nigra L. and Echinacea purpurea M. In order to evaluate the antioxidant activity various in vitro methods such as $\mathrm{Fe}^{3+}$ reducing power by FRAP method, 2,2-diphenyl-1-picryl-hydrazyl free radical (DPPH) scavenging activity, 2,2'azino-bis (3-ethylbenzthiazoline-6-sulfonic acid) radical $\left(\mathrm{ABTS}^{+}\right)$scavenging activity and Cupric reducing antioxidant capacity (CUPRAC) were performed separately. Total phenolic content ranged from $4.08 \pm 0.03$ to $20.48 \pm 0.13 \mathrm{mg}$ GAE/g DW. The established antioxidant potential of the studied plant extracts correlated significantly with total phenolic content. Both $S$. nigra flowers and A. linearis leaves extracts revealed to be the most potential. The results demonstrated the investigated ultrasound extracts as potential sources of useful properties and could contribute to different benefits in fields like pharmacy, food preparation and cosmetics.
\end{abstract}

\section{Introduction}

Despite the wide use of medical drugs, modern people still look back and use a wide range of natural products by resolving medicinal issues, maintaining their health status or just for every day well- being a concept. Medicinal plants are traditionally used from decades in the folk medicine for treatment of health problems: Centaurium erythreae Pers. - anti-inflammatory, antipyretic, hypoglycemic, antioxidant, antimicrobial, hepatoprotective, gastroprotective, etc. (Božunović et al., 2018), Glycyrrhiza glabra L. - anti-inflammatory, antiulcer, expectorant, antimicrobial and anxiolytic activities (Dhingra et al., 2004), Polygonum hydropiper L. - pain-relieving and haemorrhagic, against low blood pressure, for weight loss (Tao et al., 2016), Silene vulgaris (Moench) Garcke - good for bronchitis and asthma (Tardio et al., 2005), Aspalathus linearis L. provide relief for allergies, dermatological problems, asthma, infantile colic and other gastrointestinal complaints, such as nausea and heartburn (Joubert et al., 2008; Van Wyk et al., 2009), Helichrysum arenarium L. - treatment of urinary disorders, snake bites, sciatica and hernias (Quer, 1993), Echinacea purpurea M. - respiratory infections, urinary tract infections, skin disorders, etc. (Hobbs, 1990) and Sambucus nigra L. beneficial effects on blood pressure, glycaemia reduction, immune system stimulation, antitumor potential, increase in the activity of antioxidant enzymes in the blood plasma, including also glutathione, and the reduction of uric acid levels (Sidor and GramzaMichałowska, 2015).

Oxidative stress is involved in the pathogenesis of numerous diseases such as cardiovascular diseases (Mangge et al., 2014; He and Zuo, 2015), diabetes mellitus, Alzheimer disease (Luca et al., 2015), inflammatory diseases (Mangge et al., 2014), carcinogenesis ( $\mathrm{Li}$ et al., 2015), neurodegenerative diseases (Gandhi et al., 2012), pulmonary and hematological diseases (Imbesi et al., 2013). Studies of the toxicity exerted by synthetic antioxidants, support the regulation of these compounds use in foods, by agencies as European Food Safety Authority (EFSA) and Food and Drug Administration (FDA) (Banerjee et al., 2017), among others (IARC, 1986; EFSA, 2011, 2012). Their undesirable long-term possible toxicological effects on humans has produced, in recent years, an increasing, on 
the demand for natural antioxidants, in particular in plants, with application in the food, pharmaceutical and cosmetic sectors, since they can be used as substitutes for synthetic antioxidants (García-Alonso et al., 2004; Ferreira et al., 2006).

Phenolic acids, flavonoids, and tannins are the most commonly found polyphenolic compounds in plant extracts (Naik et al., 2006). Phenolic compounds along with plant pigments (carotenoids, chlorophylls) have proven significant antioxidant activity, which is directly correlated with removal of free radicals and superoxide (Hsu et al., 2013; Sinkovič et al., 2015). Therefore, it is important to emphasize the need to increase the consumption of foodstuffs rich in phenolic compounds aimed at preventive action on human health from cancer disease prevention to the occurrence and prevention of cardiovascular diseases (Barba et al., 2014). However, phenolic compounds exhibit a high degree of degradation in terms of technological processes and show distinct thermolability, sensitivity to light, the impact of pathogens, mechanical damage to plant tissue cells (Ross et al., 2009). Lately modern, non-invasive extraction techniques of plant metabolites with the main objective of increased extracted compound yield and a shortened period of extraction have been increasingly popularized. High-intensity ultrasound treatment does not show any degradation rates on the content of bioactive compounds in the treated food products (Koubaa et al., 2015; ŠicŽabur et al., 2015; Zinoviadou et al., 2015). In addition, the technique is applicable for the extraction of compounds with various chemical structures and is characterized by non-invasive temperatures (Koubaa et al., 2015; ŠicŽlabur et al., 2015).

The proposal of a green extraction approach using an ultrasound extraction with water will meet the challenges of the 21 st century, such as to protect both the environment and people and to enhance the competitiveness of industries to be more ecologic, economic and innovative. Water has been certified with GRAS (Generally Recognised as Safe) status by the United States Food and Drug Administration and is therefore appropriate for the manufacture of nutraceuticals along with ethanol, isopropanol and their combinations (Wang and Weller, 2006). In addition, the use of a green extraction is a part of the sustainable development and industrial strategy (Chemat et al., 2012; Rombaut et al., 2014).

The aim of the present study was the quantification of the respective antioxidant activity, emphasizing the traditional daily use of the studied plants. The ultrasound extracts obtained in accordance with the novel trends of green chemistry were analyzed and compared in respect to the presented biologically active substances.

\section{Materials and methods}

\subsection{Plant material}

The plant materials of C. erythraea, Gl. glabra., $P$. hydropiper, S. vulgaris, A. linearis, $H$. arenarium, $S$. nigra and $E$. purpurea were obtained from a herbal drugstore in Plovdiv (Bulgaria) and then was air-dried, grounded in laboratory homogenizer and stored in darkness at room temperature (Table 1).

Table 1. Bulgarian plants investigated in the present study

\begin{tabular}{|c|c|c|}
\hline Latin name & Common name & Plant part \\
\hline $\begin{array}{l}\text { Centaurium erythraea } \\
\text { Pers. }\end{array}$ & Centaury & aerial parts \\
\hline Glycyrrhiza glabra L. & Licorice & roots \\
\hline $\begin{array}{l}\text { Polygonum hydropiper } \\
\text { L. }\end{array}$ & Marsh pepper & aerial parts \\
\hline Silene vulgaris $\mathrm{L}$. & Bladder Campion & leaves \\
\hline Aspalathus linearis L. & Rooibos & leaves \\
\hline $\begin{array}{l}\text { Helichrysum arenarium } \\
\text { (L.) Moench }\end{array}$ & $\begin{array}{l}\text { Everlasting } \\
\text { Flower }\end{array}$ & flowers \\
\hline Echinacea purpurea M. & Purple coneflower & aerial parts \\
\hline Sambucus nigra $\mathrm{L}$. & $\begin{array}{l}\text { Elder, elderberry, } \\
\text { black elder }\end{array}$ & flowers \\
\hline
\end{tabular}

\subsection{Preparation of plant extracts}

The extracts were prepared by weighing $1 \mathrm{~g}$ of dry grounded plant, added to $20 \mathrm{~mL}$ of water and placed in a $250 \mathrm{~mL}$ Erlenmeyer conical flask. The ultrasonic bath (UST 5.7150 Siel, Gabrovo, Bulgaria) was operated at a frequency of $35 \mathrm{kHz}$ with a maximum input power of $240 \mathrm{~W}$, for $30 \mathrm{mins}$, at $60^{\circ} \mathrm{C}$. All obtained extracts were filtered after incubation and stored at $4{ }^{\circ} \mathrm{C}$ without adding any preservatives until analyses.

\subsection{Total polyphenol content analysis (TPC)}

The total polyphenol content was analyzed using the Folin-Ciocalteu method of Kujala et al. (2000) with some modifications. Each sample extract $(1 \mathrm{~mL})$ was mixed with $5 \mathrm{~mL}$ of Folin-Ciocalteu's phenol reagent and $4 \mathrm{ml}$ of $7.5 \% \mathrm{Na}_{2} \mathrm{CO}_{3}$. The mixture was vortexed well and left for 5 mins at $50^{\circ} \mathrm{C}$. After incubation, the absorbance was measured at $765 \mathrm{~nm}$. The TPC in the extracts was expressed as $\mathrm{mg}$ gallic acid equivalent (GAE) per g dry weight (DW).

\subsection{Antioxidant activity (AOA)}

\subsubsection{DPPH radical scavenging activity}

The ability of the extracts to donate an electron and scavenge DPPH radical was determined by the slightly modified method of Brand-Williams et al. (1995). Freshly prepared $4 \times 10^{-4} \mathrm{M}$ methanolic solution of DPPH was mixed with the samples in a ratio of 2:0.5 (v/v). The 
light absorption was measured at $517 \mathrm{~nm}$ at room temperature after 30 mins incubation. The DPPH radical scavenging activity was presented as a function of the concentration of Trolox having equivalent AOA expressed as the $\mu \mathrm{M}$ Trolox per g DW.

\subsubsection{ABTS radical cation decolorization assay}

The radicals scavenging activity of the extracts against radical cation $\left(\mathrm{ABTS}^{-+}\right)$was estimated according to a previously reported procedure with some modifications ( $\operatorname{Re}$ et al., 1999). The results were expressed as $\mu \mathrm{M}$ TE/g DW.

\subsubsection{Ferric reducing antioxidant power assay (FRAP)}

The FRAP assay was carried out according to the procedure of Benzie and Strain (1999). The FRAP reagent was prepared fresh daily and was warmed to $37^{\circ}$ $\mathrm{C}$ prior to use. The absorbance of the reaction mixture was recorded at $593 \mathrm{~nm}$ after incubation at $37^{\circ} \mathrm{C}$ for 4 mins. The results were expressed as $\mu \mathrm{M} \mathrm{TE} / \mathrm{g} \mathrm{DW}$.

\subsubsection{Copper reduction assay (CUPRAC)}

CUPRAC assay was performed according to the method of Apak et al. (2004). To a test tube were added $1 \mathrm{~mL}$ of $\mathrm{CuCl}_{2}$ solution $\left(1.0 \times 10^{-2} \mathrm{M}\right), 1 \mathrm{~mL}$ of neocuproine-methanolic solution $\left(7.5 \times 10^{-3} \mathrm{M}\right)$, and $1 \mathrm{~mL}$ $\mathrm{NH}_{4} \mathrm{Ac}$ buffer solution ( $\mathrm{pH} 7.0$ ), and mixed; $0.1 \mathrm{~mL}$ of herbal extract (sample) followed by $1 \mathrm{~mL}$ of water were added (total volume of $4.1 \mathrm{~mL}$ ), and mixed well. Absorbance against a reagent blank was measured at 450 $\mathrm{nm}$ after 30 mins. Trolox was used as standard and total antioxidant capacity of herbal extracts was expressed as $\mu \mathrm{M}$ TE/g DW.

\subsection{Statistical analysis}

The results obtained are average from two independent experiments carried out in triplicates. The values were expressed as mean $\pm \mathrm{SD}$, analyzed using MS Excel 2007 software.

\section{Results and discussion}

\subsection{Total polyphenol content}

Plant polyphenols are a significant group of compounds acting as free radical scavengers or primary antioxidants. The results regarding the total phenolic content of the studied water ultrasound extracts are presented in Table 2. The established total phenolic content varied from $4.08 \pm 0.03$ to $20.48 \pm 0.13 \mathrm{mg}$ GAE$/ \mathrm{g}$ DW. The highest values were determined for $S$. nigra and A. linearis (20.48 \pm 0.13 and $12.65 \pm 0.03 \mathrm{mg} \mathrm{GAE} / \mathrm{g}$ DW, respectively) and the lowest result was established in the C. erythraea ultrasound extract $-4.08 \pm 0.03 \mathrm{mg}$ $\mathrm{GAE} / \mathrm{g}$ DW.

Oniszczuk et al. (2016) conducted ultrasonic extraction of $S$. nigra at $60^{\circ} \mathrm{C}$ and established the presence of various phenolic acids and flavonoids. According to Viapiana and Wesolowski (2017), the TPC of $S$. nigra flowers infusions ranged from 15.23 to 35.57 mg GAE/g DW, whereas Veljković et al. (2013) detected TPC of $42.67 \mathrm{~g} \mathrm{GAE} / \mathrm{kg}$ DW. In comparison, Boukhira et al. (2015) established TPC of $3.35 \pm 0.12 \mathrm{mg} \mathrm{GA} / \mathrm{g}$ of extract in the ultrasound-assisted extract of $S$. vulgaris from Morocco and Kiselova et al. (2006) established TPC for infusion of $A$. linearis of $437.90 \pm 1.11 \mu \mathrm{M} \mathrm{QE}$. Compared to the report by Petkova et al. (2017) TPC for E. purpurea microwave extract $(24.1 \pm 1.1 \mathrm{mg} \mathrm{GAE} / \mathrm{g}$ DW), our findings are lower - 8.02 $\pm 0.06 \mathrm{mg} \mathrm{GAE} / \mathrm{g}$ DW. This could be due to the evaluation procedure differences and the plant sample variations. The phenolic compounds present in plant material may range from simple to highly polymerized. The different types and quantities of phenolic compounds also differ among plant types, and these may interact with proteins and carbohydrates to form insoluble complexes. The complete recovery of phenolics from plant material is therefore not always possible (Takeuchi et al., 2009).

\subsection{Antioxidant activity}

The antioxidant ability and radical scavenging properties of plants are commonly associated with their medicinal value. The studied in the present research plants were widely used in traditional medicine. In accordance with the recommendations for at least two (Schlesier et al., 2002) methods for antioxidant activity assessment, four reliable methods were employed in the present study. However, it is very difficult to select the most suitable antioxidant assay method due to the various mechanisms of antioxidant action (Badarinath et

Table 2. Total phenol content (mg GAE/g DW) and in vitro antioxidant activity ( $\mu \mathrm{M} \mathrm{TE} / \mathrm{g} \mathrm{DW}$ ) of ultrasound-assisted extracts

\begin{tabular}{lccccc}
\multicolumn{1}{c}{ Sample/assay } & TPC & DPPH & ABTS & FRAP & CUPRAC \\
\hline C. erythraea & $4.08 \pm 0.03$ & $41.16 \pm 0.40$ & $27.37 \pm 0.12$ & $50.99 \pm 0.30$ & $43.92 \pm 0.41$ \\
G. glabra & $6.18 \pm 0.01$ & $61.32 \pm 0.76$ & $29.59 \pm 0.29$ & $34.16 \pm 0.55$ & $34.91 \pm 0.69$ \\
P. hydropiper & $5.80 \pm 0.03$ & $85.22 \pm 0.26$ & $70.00 \pm 1.67$ & $107.53 \pm 0.58$ & $108.75 \pm 1.20$ \\
S. vulgaris & $6.36 \pm 0.06$ & $63.24 \pm 1.39$ & $73.16 \pm 1.80$ & $75.96 \pm 0.80$ & $84.54 \pm 1.26$ \\
A. linearis & $12.65 \pm 0.03$ & $166.64 \pm 1.07$ & $83.01 \pm 1.36$ & $222.32 \pm 0.87$ & $263.72 \pm 3.85$ \\
H. arenarium & $8.31 \pm 0.03$ & $79.98 \pm 0.60$ & $34.54 \pm 0.21$ & $86.14 \pm 0.62$ & $124.55 \pm 0.48$ \\
E. purpurea & $8.02 \pm 0.06$ & $70.03 \pm 0.89$ & $18.33 \pm 0.33$ & $93.94 \pm 1.27$ & $196.88 \pm 2.88$ \\
S. nigra & $20.48 \pm 0.13$ & $281.42 \pm 1.63$ & $144.54 \pm 2.21$ & $273.60 \pm 2.81$ & $407.96 \pm 6.96$ \\
\hline
\end{tabular}


al., 2010).

According to the DPPH assay (Table 2) the highest results were recorded for $S$. nigra extract followed by $A$. linearis extract $-281.42 \pm 1.63$ and $166.64 \pm 1.07 \mu \mathrm{M}$ TE/g DW, respectively. The lowest value was established for C. erythraea - $41.16 \pm 0.40 \mu \mathrm{M} \mathrm{TE} / \mathrm{g} \mathrm{DW}$. The results were in accordance with the total phenolic content established. Other authors determined the antioxidant activity of $S$. nigra flower infusions from $0.57 \pm 0.07$ to $0.92 \pm 0.01 \mathrm{mM} \mathrm{TE} / \mathrm{g}$ DW toward DPPH (Viapiana and Wesolowski, 2017). According to the ABTS assay (Table 2), the highest results were established for $S$. nigra and A. linearis - $144.54 \pm 2.21$ and $83.01 \pm 1.36 \mu \mathrm{M}$ TE/g DW, respectively and the lowest was evaluated in C. erythraea $27.37 \pm 0.12 \mu \mathrm{M} \mathrm{TE} / \mathrm{g}$ DW. MikulicPetkovsek et al. (2016) reported significant variation in ABTS scavenging activity among Sambucus species and hybrids in a range from 44.87 to $118.26 \mathrm{mM} \mathrm{TE} / \mathrm{kg} \mathrm{DW}$. The results, according to the conducted FRAP test, were in accordance with already established (Table 2). In particular, the highest antioxidant activity was evaluated in the $S$. nigra extract followed by A. linearis extract $273.60 \pm 2.81$ and $222.32 \pm 0.87 \mu \mathrm{M} \quad \mathrm{TE} / \mathrm{g} \quad \mathrm{DW}$, respectively. Among the investigated ultrasound extracts the lowest values were established in G. glabra and $C$. erythraea samples- $34.16 \pm 0.55$ and $50.99 \pm 0.30 \mu \mathrm{M}$ TE/g DW, respectively. In comparison Marhev et al. (2013) established in ultrasound acetone extracts of $S$. nigra values between $13.58 \pm 0.10$ and $31.29 \pm 0.37 \mathrm{mM} \mathrm{TE} / \mathrm{g}$ $\mathrm{dw}$. In respect of CUPRAC assay, $S$. nigra extract $(407.96 \pm 6.96 \mu \mathrm{M}$ TE/g DW) followed by A. linearis extract $(263.72 \pm 3.85 \mu \mathrm{M}$ TE/g DW) were established with the highest antioxidant potential. The lowest values were established in G. glabra and C. erythraea extracts. Marhev et al. (2013) established in ultrasound acetone extracts of $S$. nigra flowers values between $49.88 \pm 1.23$ and $108.54 \pm 1.43 \mathrm{mM} \mathrm{TE} / \mathrm{g} \mathrm{dw}$ according to CUPRAC assay.

Table 3. Correlation coefficients (r) for relationships between assays

\begin{tabular}{lcccc}
\hline \multicolumn{1}{c}{$\begin{array}{c}\text { Correlation } \\
\text { coefficients }\end{array}$} & DPPH & ABTS & FRAP & CUPRAC \\
\hline TPC & 0.9823 & 0.8318 & 0.9332 & 0.9595 \\
CUPRAC & 0.9409 & 0.7743 & 0.9551 & \\
FRAP & 0.9580 & 0.8632 & & \\
ABTS & 0.8968 & & & \\
\hline
\end{tabular}

Correlation analysis between total phenolics and antioxidant capacity are shown in Table 3. The established coefficients varied between 0.7743 and 0.9823, which mean significant correlation between assays conducted. However, the strongest correlation was established between TPC and DPPH assay (0.9823). It has to be noted that a weaker correlation was observed when involving the ABTS assay. This indicates the fact that single assay may not be used to assess comprehensively the antioxidant activity and confirmed the trend for using at least three different assays.

\section{Conclusion}

Nowadays, the ultrasound-assisted method is extensively used for the extraction of valuable molecules. The present paper evaluates the biological activity resulted from applying this green chemistry approach. Among the studied plants, S. nigra flowers and $A$. linearis leaves extracts revealed to be the most effective in respect of total polyphenolic content and antioxidant capacities. The extracts could be used as potent sources of biologically active substances. However, the exact mechanism of action of the extracts in vivo definitely must be conducted as further research in order to interpret their functionality.

\section{Conflict of Interest}

The authors declare no conflict of interest.

\section{References}

Apak, R., Güçlü, K., Ozyürek, M. and Karademir, S.E. (2004). Novel total antioxidant capacity index for dietary polyphenols and vitamins $\mathrm{C}$ and $\mathrm{E}$, using their cupric ion reducing capability in the presence of neocuproine: CUPRAC method. Journal of Agricultural and Food Chemistry, 52(26), 79707981. https://doi.org/10.1021/jf048741x

Badarinath, A.V., Mallikarjuna Rao, K., Chetty, C.M.S., Ramkanth, S., Rajan, T.V.S and Gnanaprakash, K. (2010). A Review on in-vitro antioxidant methods: Comparisions, correlations and considerations. International Journal of PharmTech Research, 2(2), 1276-1285.

Banerjee, R., Verma, A.K. and Siddiqui, M.W. (2017). Natural Antioxidants: Applications in Foods of Animal Origin. 1st ed. USA: CRC Press.

Barba, F.J., Esteve, M.J. and Frígola, A. (2014) Bioactive components from leaf vegetable products. Studies in Natural Products Chemistry, 41, 321-346. https://doi.org/10.1016/B978-0-444-63294-4.000115

Benzie, I.F. and Strain, J.J. (1999). Ferric reducing/ antioxidant power assay: Direct measure of total antioxidant activity of biological fluids and modified version for simultaneous measurement of total antioxidant power and ascorbic acid concentration. Methods in Enzymology, 299, 15-27. https:// doi.org/10.1016/S0076-6879(99)99005-5 
Boukhira, S., Bousta, D., El Mansouri, L., Nordine, A., Hamsas El Youbi, A. and Daoudi, A. (2015). Antioxidant activity and protective effect on DNA damage and deoxyribose of Silene vulgaris (Moench) Garcke from Morocco. International Journal of Pharmacognosy and Phytochemical Research, 7(6), 1172 - 1178.

Božunović, J., Živković, S., Gašić, U., Glamočlija, J., Ćirić, A., Matekalo, D., Šiler, B., Soković, M., Tešić, Ž. and Mišić, D. (2018). In vitro and in vivo transformations of Centaurium erythraea secoiridoid glucosides alternate their antioxidant and antimicrobial capacity. Industrial Crops and Products, 111, 705-721. http://dx.doi.org/10.1016/ j.indcrop.2017.11.040

Brand-Williams, W., Cuvelier, M.E. and Berset, C. (1995). Use of a free radical method to evaluate antioxidant activity. LWT - Food Science and Technology, 28(1), 25-30. https://doi.org/10.1016/ S0023-6438(95)80008-5

Chemat, F., Vian, M.A. and Cravotto, G. (2012). Green extraction of natural products: concept and principles. International Journal of Molecular Science, 13(7), 8615-8627. https://doi.org/10.3390/ ijms13078615

Dhingra, D., Parle, M. and Kulkarni, S.K. (2004). Memory enhancing activity of Glycyrrhiza glabra in mice. Journal of Ethnopharmacology, 91(2-3), 361365. https://doi.org/10.1016/j.jep.2004.01.016

Aguilar, F., Crebelli, R., Dusemund, B., Galtier, P., Gilbert, J., Gott, D.M., Gundert-Remi, U., Koenig, J., Lambré, C., Leblanc, J-C., Mortensen, A., Mossesso, P., Parent-Massin, D., Rietjens, I.M.C.M., Stankovic, I., Tobback, P., Waalkens-Berendsen, I., Woutersen, R.A. and Wright, M. (2011). Scientific opinion on the re-evaluation of butylatedhydroxyanisole - BHA, EFSA Journal, 9 (10), 2392-441. https://doi.org/10.2903/ j.efsa.2011.2392

Ferreira, A., Proença, C., Serralheiro, M.L.M. and Araujo, M.E.M. (2006). The in vitro screening for acetylcholinesterase inhibition and antioxidant activity of medicinal plants from Portugal. Journal of Ethnopharmacology, 108(1), 31-37. https:// doi.org/10.1016/j.jep.2006.04.010

Gandhi, S. and Abramov, A.Y. (2012). Mechanism of oxidative stress in neurodegeneration. Oxidative Medicine and Cellular Longevity, 428010, 1-11. http://dx.doi.org/10.1155/2012/428010

García-Alonso, M., Pascual-Teresa, S., Santos-Buelga, C. and Rivas-Gonzalo, J.C. (2004). Evaluation of the antioxidant properties of fruits. Food Chemistry, 84 (1), 13-18. https://doi.org/10.1016/S0308-8146(03)

\section{0-2}

He, F. and Zuo, L. (2015). Redox Roles of Reactive Oxygen Species in Cardiovascular Diseases. International Journal of Molecular Science, 16(11), 27770-27780. https://dx.doi.org/10.3390\% 2Fijms161126059

Hobbs, C. (1990). Echinacea: The Immune Herb. Santa Cruz, California USA: American Botanical Council, Botanica Press.

Hsu, C.Y., Chao, P.Y., Hu, S.P. and Yang, C.M. (2013). The Antioxidant and free radical scavenging activities of chlorophylls and pheophytins. Food and Nutrition Sciences, 4, 1-8. http://dx.doi.org/10.4236/ fns.2013.48A001

Imbesi, S., Musolino, C., Allegra, A., Saija, A., Morabito, F., Calapai, G. and Gangemi, S. (2013). Oxidative stress in oncohematologic diseases: an update. Expert Review of Hematology, 6(3), 317325. https://doi.org/10.1586/ehm.13.21

1ARC (International Agency for Research on Cancer). (1986). IARC monographs on the evaluation of carcinogenic risks to humans, Monograph 40. Geneva: World Health Organization

Joubert, E., Gelderblom, W.C.A., Louw, A. and De Beer, D. (2008). South African herbal teas: Aspalathuslinearis, Cyclopia spp. and Athrixiaphylicoides - a review. Journal of Ethnopharmacology, 119(3), 376-412. https:// doi.org/10.1016/j.jep.2008.06.014

Kiselova, Y., Ivanova, D., Chervenkov, T., Gerova, D., Galunska, B. and Yankova, T. (2006). Correlation between the in vitro antioxidant activity and polyphenol content of aqueous extracts from Bulgarian herbs. Phytotherapy Research, 20(11), 961-965. https://doi.org/10.1002/ptr.1985

Koubaa, M., Roselló-Soto, E., ŠicŽlabur, J., RežekJambrak, A., Brnčić, M., Grimi, N., Boussetta, N. and Barba, F.J. (2015). Current and new insights in the sustainable and green recovery of nutritionally valuable compounds from Stevia rebaudiana Bertoni. Journal of Agricultural and Food Chemistry, 63(31), 6835-6846. https:// doi.org/10.1021/acs.jafc.5b01994

Kujala, T.S., Loponen, J.M., Klika, K.D. and Pihlaja, K. (2000). Phenolics and betacyanins in red beetroot (Beta vulgaris) root: Distribution and effect of cold storage on the content of total phenolics and three individual compounds. Journal of Agricultural and Food Chemistry, 48(11), 5338-5342. https://doi.org/10.1021/jf000523q

Li, S., Tan, H.-Y., Wang, N., Zhang, Z.-J., Lao, L., Wong, C.-W. and Feng, Y. (2015). The role of 
oxidative stress and antioxidants in liver diseases. International Journal of Molecular Science, 16(11), 26087- 26124. https://doi.org/10.3390/ ijms 161125942

Luca, M., Luca, A. and Calandra, C. (2015). The Role of oxidative damage in the pathogenesis and progression of Alzheimer's disease and vascular dementia. Oxidative Medicine and Cellular Longevity, $\quad 504678, \quad 1-8 . \quad$ https:// doi.org/10.1155/2015/504678

Mangge, H., Becker, K., Fuchs, D. and Gostner, J.M. (2014). Antioxidants, inflammation and cardiovascular disease. World Journal of Cardiology, 6(6), 462-477. https://doi.org/10.4330/ wjc.v6.i6.462

Marhev, A., Seimenska, D., Denev, P., Pavlov, A. and Kratchanova, M. (2013). Fruit and flowers of Sambucus nigra and Sambucus ebulus - a rich source of biologically active triterpenoids with antioxidant and anti-inflammatory activities. Nauka I Dietetika, 3, 28- 33 (in Bulgarian).

Mikulic-Petkovsek, M., Ivancic, A., Schmitzer, V., Veberic, R. and Stampar, F. (2016). Comparison of major taste compounds and antioxidative properties of fruits and flowers of different Sambucus species and interspecific hybrids. Food Chemistry, 200, 134140. https://doi.org/10.1016/j.foodchem.2016.01.044

Naik, G.H., Priyadarsini, K.I. and Mohan, H. (2006). Free radical scavenging reactions and photochemical analysis of triphala, an ayurvedic formulation. Current Science, 90(8), 1100-1105.

Oniszczuk, A., Olech, M., Oniszczuk, T., WojtunikKulesza, K. and Wójtowicz, A. (2016). Extraction methods, LC-ESI-MS/MS analysis of phenolic compounds and antiradical properties of functional food enriched with elderberry flowers or fruits. Arabian Journal of Chemistry. [In Press]. https:// doi.org/10.1016/j.arabjc.2016.09.003

Quer, P.F. (1993). Plantas medicinales: el Dioscórides Renovado. 14th ed. Barcelona, Spanish: Editoral Labor, S.A.

Petkova, N., Ivanova, L., Filova, G., Ivanov, I. and Denev, P. (2017). Antioxidants and carbohydrate content in infusions and microwave extracts from eight medicinal plants. Journal of Applied Pharmaceutical Science, 7(10), 055- 061. https:// doi.org/10.7324/JAPS.2017.71008

Re, R., Pellegrini, N., Proteggente, A., Pannala, A., Yang, M. and Rice-Evans, C. (1999). Antioxidant activity applying an improved ABTS radical cationdecolorization assay. Free Radical Biology and Medicine, 26(9-10), 1231-1237. https://
doi.org/10.1016/S0891-5849(98)00315-3

Rombaut, N., Tixier, A.S., Bily, A. and Chemat, F. (2014). Green extraction processes of natural products as tools for biorefinery. Biofuels, Bioproducts and Biorefining, 8(4), 530-544. https:// doi.org/10.1002/bbb.1486

Ross, K.A., Beta, T. and Arntfield, S.D. (2009). A comparative study on the phenolic acids identified and quantified in dry beans using HPLC as affected by different extraction and hydrolysis methods. Food Chemistry, 113(1), 336-344. https://doi.org/10.1016/ j.foodchem.2008.07.064

Schlesier, K., Harwat, M., Böhm, V. and Bitsch, R. (2002). Assessment of antioxidant activity by using different in vitro methods. Free Radical Research, 36(2), $\quad 177 \quad-\quad 187 . \quad$ https:// doi.org/10.1080/10715760290006411

ŠicŽlabur, J., Voća, S., Dobričević, N., RimacBrnčić, S., Dujmić, F. and Brnčić, M. (2015). Optimization of ultrasound assisted extraction of functional ingredients from Stevia rebaudiana Bertoni leaves. International Agrophysics, 29(2), 231-237. https:// doi.org/10.1515/intag-2015-0017

Sidor, A. and Gramza-Michałowska, A. (2015). Advanced research on the antioxidant and health benefit of elderberry (Sambucusnigra) in food - a review. Journal of Functional Foods, 18(B), 941958. http://dx.doi.org/10.1016\%2Fj.jff.2014.07.012

Sinkovič, L., Demšar, L., Žnidarčič, D., Vidrih, R., Hribar, J. and Treutter, D. (2015). Phenolic profiles in leaves of chicory cultivars (Cichorium intybus L.) as influenced by organic and mineral fertilizers. Food Chemistry, 166, 507-513. https:// doi.org/10.1016/j.foodchem.2014.06.024

Takeuchi, T.M., Pereira, C.G., Braga, M.E.M., Maróstica, M.R., Leal, P.F. and Meireles, M.A.A. (2009). Low-pressure solvent extraction (solid-liquid extraction, microwave assisted, and ultrasound assisted) from condimentary plants. In Meireles, M.A.A. (Ed.). Extracting Bioactive Compounds for Food Products: Theory and Applications, p. 138211. New York: Taylor and Francis Group, LLC. https://doi.org/10.1201/9781420062397.ch4

Tao, J., Wei, Y. and Hu, T. (2016). Flavonoids of Polygonum hydropiper L. attenuates lipopolysaccharide-induced inflammatory injury via suppressing phosphorylation in MAPKs pathways. BMC Complementary and Alternative Medicine, 16, 25. https://doi.org/10.1186/s12906-016-1001-8

Tardio, J., Pascual, H. and Morales, R. (2005). Wild food plants traditionally used in the province of Madrid, Central Spain. Economic Botany, 59, 122-136. 
https://doi.org/ 10.1663/0013-0001(2005)059\%

5B0122:WFPTUI\%5D2.0.CO;2

Van Wyk, B.-E., Van Oudtshoorn, B. and Gericke, N. (2009). Medicinal Plants of South Africa. Chromatographia, 71(11-12), 1151 https:// doi.org/10.1365/s10337-010-1583-0

Veljković, J N., Pavlović, A N., Mitić, S.S., Tošić, S.B., Stojanović, G.S., Kalićanin, B.M., Stanković, D.M., Stojković, M.B., Mitić, M.N. and Brcanović, J.M. (2013). Evaluation of individual phenolic compounds and antioxidant properties of black, green, herbal and fruit tea infusions consumed in Serbia: spectrophotometrical and electrochemical approaches. Journal of Food and Nutrition Research, 52(1), 12-24.

Viapiana, A. and Wesolowski, M. (2017). The Phenolic Contents and Antioxidant Activities of Infusions of Sambucusnigra L. Plant Foods for Human Nutrition (Dordrecht, Netherlands), 72(1), 82-87. https:// dx.doi.org/10.1007\%2Fs11130-016-0594-x

Wang, L. and Weller, C.L. (2006). Recent advances in extraction of nutraceuticals from plants. Trends in Food Science and Technology, 17(6), 300-312. https://doi.org/10.1016/j.tifs.2005.12.004

Zinoviadou, K.G., Galanakis, C.M, Brnčić, M., Grimi, N., Boussetta, N., Mota, M.J., Saraiva, J., Patras, A., Tiwari, B.K. and Barba, F.J. (2015). Fruit juice sonication: Implications on food safety, physicochemical and nutritional properties. Food Research International, 77(4), 743-752. http:// dx.doi.org/10.1016\%2Fj.foodres.2015.05.032 